\title{
Biomechanical and histological evaluation of glycerol-preserved human sclerae
}

\section{Avaliação biomecânica e histológica de escleras humanas preservadas em glicerol}

\author{
Tarciso Schirmbeck ${ }^{1}$ \\ Antonio Augusto Velascoe Cruz ${ }^{2}$
}

Study performed at the Department of Ophthalmology, Otorhinolaryngology and Head and Neck Surgery, Faculdade de Medicina de Ribeirão Preto - Universidade de São Paulo - USP - Ribeirao Preto (SP) - Brazil.

PhD. Department of Ophthalmology, Otorhinolaryngology and Head and Neck Surgery, Faculdade de Medicina de Ribeirão Preto - Universidade de São Paulo USP - Ribeirão Preto (SP) - Brazil.

${ }^{2}$ Full Professor, Department of Ophthalmology, Otorhinolaryngology and Head and Neck Surgery, Faculdade de Medicina de Ribeirão Preto - USP - Ribeirão Preto (SP) - Brazil.

Correspondence: Antonio Augusto Velasco e Cruz. Department of Ophthalmology, Otorhinolaryngology and Head and Neck Surgery, Faculdade de Medicina de Ribeirão Preto - Universidade de São Paulo - USP Ribeirão Preto (SP) - Brazil. CEP 14049-900

E-mail: aavecruz@fmrp.usp.br

Recebido para publicação em 12.04 .2007

Última versão recebida em 20.06.2007

Aprovação em 25.06.2007

\section{INTRODUCTION}

Since the beginning of the $19^{\text {th }}$ century, when fascia lata was first used for eyelid surgery ${ }^{(1)}$, there has been continued interest in employing different preserved tissues in ophthalmologic surgery ${ }^{(2)}$. Human sclera is one of the most used preserved human tissue due to its structural stability and low inflammation induction ${ }^{(3)}$. In fact, sclera is widely in used in oculoplasty for wrapping intraorbital implants, in glaucoma surgery for protecting filtering devices and in cases of scleral thinning ${ }^{(4-6)}$.

Various methods have been employed to preserve the sclera ${ }^{(7-9)}$ including the use of glycerol. The sterilizing properties of glycerol are well known, but its effect on the biomechanical properties of the sclera has not been characterized. In the present study we evaluated the effect of glycerol on mechanical resistance and elasticity of human sclera.

\section{METHODS}

A total of 114 paired human cadaver eyes, obtained from the Federal District Eye bank, were used in the study. The sclerae were removed from the eyes, cleaned and preserved with $98 \%$ glycerol under refrigeration at 4 to $8^{\circ} \mathrm{C}$. The sample was divided into a control group with no preservation 
and 5 groups of 19 scleras in $7,15,30,90$ and 180 days of preservation.

Before biomechanical evaluation all specimens were hydrated for 30 minutes in a $0.9 \%$ saline solution. After hydration, two fragments were taken from the equatorial region: a $3 \times 3 \mathrm{~mm}$ fragment for histological examination stained with hematoxylin and eosin and Mallory's trichrome and a $10 \mathrm{~mm}$ wide scleral ring to determine the load required to rupture the tissue. For this test, the scleral rings were fixed between two cylindrical muskets, and progressive weights were added until rupture of the ring. Tissue distension was measured with an apparatus consisting of a system of weights associated with a deflectometer with $0.01 \mathrm{~mm}$-sensitivity.

\section{RESULTS}

Histological evaluation showed that glycerol preservation did not change the basic structure of the scleral tissue. No signs of degradation were detected in any of the tissue samples examined. Typically in the superficial region of the sclera there were bundles of collagen fibrils in a lamellar pattern parallel or perpendicular to the surface. In the deepest region, the bundles were arranged in various spatial directions, forming distinct angles between the fibers. Some sclerocytes could be visualized, mainly in sclerae in natura (Figure 1).

Biomechanical evaluation revealed that glycerol significantly changed the elasticity of preserved tissues. As shown in figure 2, a non-preserved human sclera distends linearly in response to increasing loads until the tissue breaks down. Glycerol did not change the linearity but increased the slope of the function indicating that the preserved tissue is less distensible. This effect is also evident in figure 3, displaying the mean load necessary to rupture the tissue according to
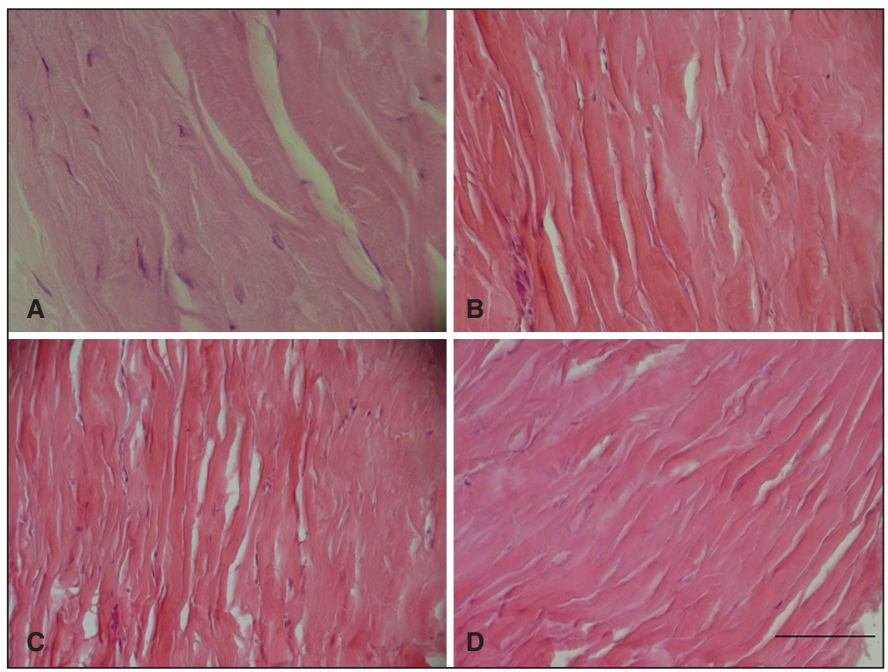

Figure 1 - Histological appearance of scleral tissue: a) non-preserved; b, c and d): 30, 90 and 180 days of preservation, respectively. Horizontal line $=50 \mu \mathrm{m}$. preservation time. The function has a sigmoid shape reaching a plateau after 90 days of preservation. In fact, one-way analysis of variance with post hoc analysis by Tukey test revealed that the load necessary to break down the sclerae increased significantly only after 90 days of preservation. After this time, the mechanical properties of the tissue remained stable and the load necessary to rupture the tissue did not change.

\section{DISCUSSION}

Sclera is a dense tissue predominantly consisting of collagen arranged in bundles of fibrils with different orienta-

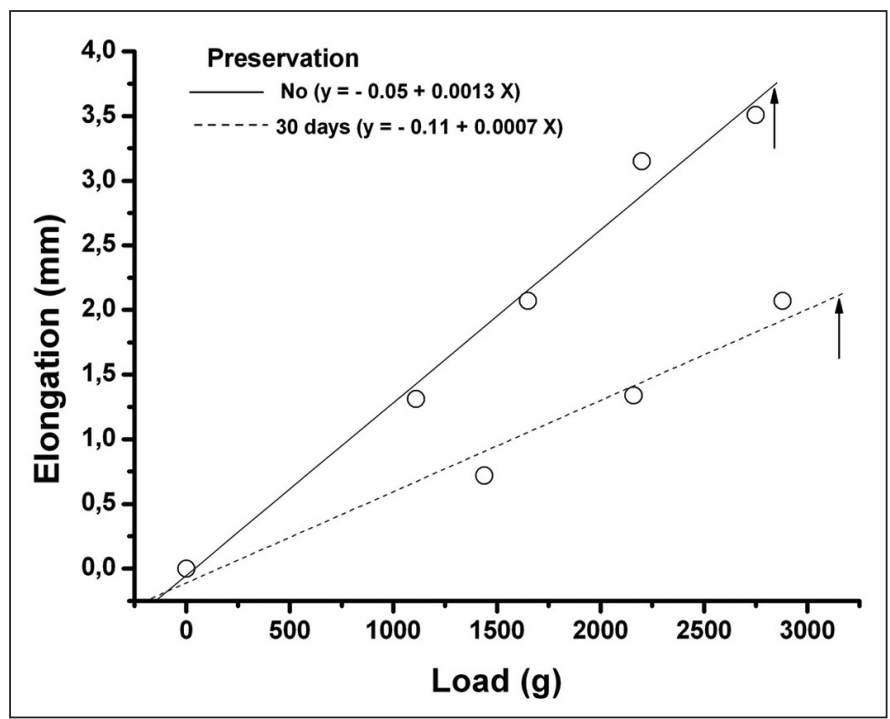

Figure 2 - Linear relation between load and elongation of preserved (30 days) and non-preserved sclerae

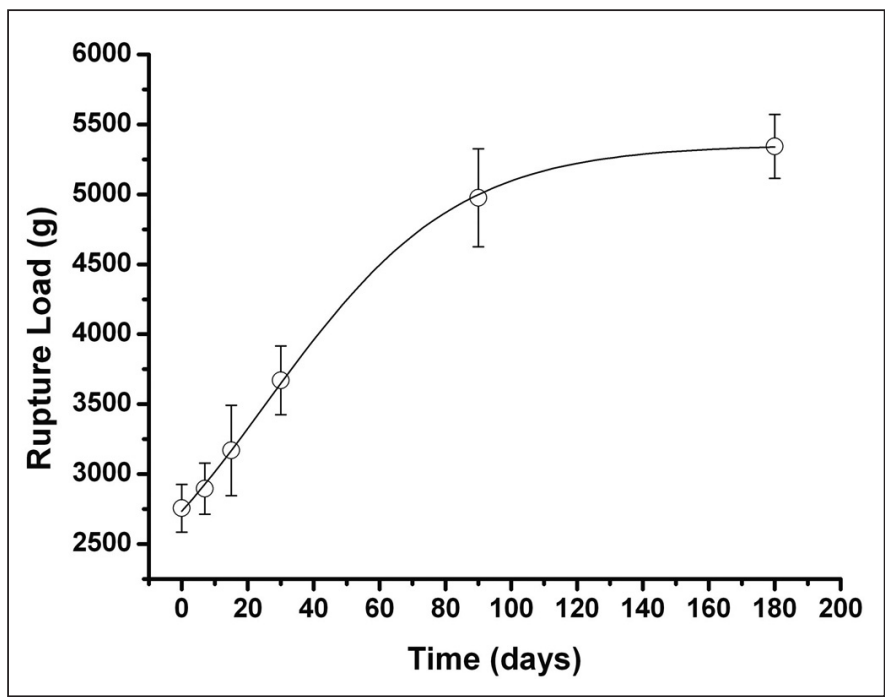

Figure 3 - Effect of preservation time on the load necessary to rupture the scleral tissue 
tions ${ }^{(10)}$. The histological analysis of preserved sclerae revealed that this structure does not change with glycerol preservation process. The fibril arrangement and spatial orientation, as well the interfibrillar space, were unchanged in the preserved samples even after storage for 80 days. The ability of glycerol to keep the collagen configuration is related to its mechanism of action. Glycerol acts by dehydration, substituting the collagen links with water molecules provided by its hydroxyl groups ${ }^{(11)}$. Dehydration caused by high concentrations of glycerol inhibits enzymatic reactions which depend on water. The rate of protein denaturation is thus minimized $^{(11)}$.

The decreased number of sclerocytes in the preserved tissues is probably also related to both osmotic stress and chemical toxicity of high concentrations of glycerol. Such cellular decrease was also noticed in preservation of aortic tissue in mice ${ }^{(12)}$. The loss of cells in preserved tissues is not a problem; on the contrary, whenever the use of preserved sclera is necessary in ophthalmologic surgeries, cellular integrity is not fundamental. In fact such cellular degradation is considered beneficial since the antigenic properties of the implant would be smaller, with fewer inflammatory reactions $^{(12)}$.

The mechanical properties of the sclera, either in their natural condition or after being preserved, are closely related to collagen fibrils and their interaction with substances present in the extracellular matrix ${ }^{(13)}$. When any material is submitted to traction, a certain amount of elongation always occurs. Initially, the traction force realigns the molecules of the tissue, and then elongation starts by sliding on specific planes. Traction load depends not only on the mechanical properties of the material, but also on the spatial orientation of its constituent. Rupture occurs when the plastic properties of the material are overcome by traction load ${ }^{(14)}$.

The present study showed diminished distension and increased mechanical resistance of the preserved scleral tissue. Clearly the load necessary to rupture the collagen fibrils depends on hydration of the extracellular matrix. The dehydration induced by glycerol makes the sliding of collagen molecules more difficult. Besides, the interaction of the glycerol molecules through their hydroxyl groups increases resistance to lengthening.

Surgeons using preserved sclerae in ophthalmic surgeries should keep in mind that they are dealing with a less distensible tissue than a non-preserved one. Theoretically, stiffness induced by the preservation process could be an advantage in cases were the tissue would be used as a spacer. A typical example is the correction of lower eyelid retraction, a situation that demands a material with a certain degree of resistance. However, for other uses, such as wrapping intraorbital implants, the reduced elasticity of the material can be a factor of implant exposure, especially when large implants are required. To avoid exposure the sutures should be placed without tension, a fact that requires a large quantity of coating material.

\section{RESUMO}

Objetivo: Determinar as características histológicas e biomecânicas de escleras humanas preservadas em glicerol. Métodos: Escleras de ambos os olhos de 55 doadores foram limpas e preservadas com glicerol a $98 \%$ sob refrigeração (4 a $8^{\circ} \mathrm{C}$ ). A amostra foi dividida em grupo controle sem preservação e 5 grupos de 19 escleras com 7, 15, 30, 90 e 180 dias de preservação. Todas as amostras foram submetidas à avaliação histológica e aos testes de tração e distensão. Resultados: A preservação em glicerol não provocou alterações na arquitetura histológica do tecido escleral. A carga média necessária para romper o tecido escleral aumentou com o tempo de preservação segundo uma função sigmóide. Um incremento significativo na resistência mecânica e diminuição da elasticidade do tecido ocorreram após 90 dias de preservação. Conclusões: A preservação escleral com glicerol mantém a integridade tecidual. O material preservado torna-se menos distensível após 90 dias de preservação. Cirurgiões que usam esclera preservada em procedimentos oftalmológicos devem estar conscientes das propriedades mecânicas do material e levar em conta o tempo de preservação do material.

Descritores: Esclera/efeito de drogas; Glicerol; Preservação de tecido; Histologia

\section{REFERENCES}

1. Beyer CK, Albert DM. The use and fate of fascia lata and sclera in ophthalmic plastic and reconstructive surgery. Ophthalmology. 1981;88(9): 869-86.

2. DeBacker CM, Dutton JJ, Proia AD, Stone T, Holck DE. A comparative study of bovine pericardium (periguard) and homologous sclera as lower eyelid spacer graft analogs in New Zealand white rabbits. Ophthal Plast Reconstr Surg. 2000;16(2):156-61.

3. Kadoi C, Hayasaka S, Kato T, Nagaki Y, Matsumoto M, Hayasaka Y. The cutler-beard bridge flap technique with use of donor sclera for upper eyelid reconstruction. Ophthalmologica. 2000;214(2):140-2.

4. Detorakis ET, Ioannakis K, Drakonaki EE, Ganasouli D, Kozobolis VP. Processed fascia lata as an alternative implant material in evisceration. Ophthal Plast Reconstr Surg. 2005;21(2):133-7.

5. Oh JH, Kim JC. Repair of scleromalacia using preserved scleral graft with amniotic membrane transplantation. Cornea. 2003;22(4):288-93.

6. Molteno AC. New implant for drainage in glaucoma. Clinical trial. Br J Ophthalmol. 1969;53(9):606-15.

7. Dailey JR, Rosenwasser GO. Viability of bacteria in glycerin and ethanol preserved sclera. J Refract Corneal Surg. 1994;10(1):38-40.

8. Lucci LM, Yu MC, Höfling-Lima AL. Decontamination of human sclera: an in vitro study. Cornea. 1999;18(5):595-8.

9. Dziedzic-Goclawska A, Kaminski A, Uhrynowska-Tyszkiewicz I, Stachowicz W. Irradiation as a safety procedure in tissue banking. Cell Tissue Bank. 2005;6(3):201-19.

10. Komai Y, Ushiki T. The three-dimensional organization of collagen fibrils in the human cornea and sclera. Invest Ophthalmol Vis Sci. 1991;32(8):2244-58.

11. Penkova R, Goshev I, Gorinstein S, Nedkov P. Stability of collagen during denaturation. J Protein Chem. 1999;18(4):397-401.

12. Fahner PJ, Idu MM, Legemate DA, Vanbavel E, Borstlap J, Pfaffendorf M, et al. Morphological and functional alterations in glycerol preserved rat aortic allografts. Int J Artif Organs. 2004;27(11):979-89.

13. Gloster J, Perkins ES. Distensibility of the human eye. Br J Ophthalmol. 1959;43(2):97-101.

14. Timoshenko S. Resistência dos materiais: Propriedades mecânicas dos materiais. Rio de Janeiro: Ao Livro Técnico; 1966. v.2. cap.10. p.360-93. 